\title{
Prolongation of duration of ovulation in ageing mice
}

\author{
H. Ishikawa and A. Endo* \\ Department of Hygiene and Preventive Medicine, Yamagata University School of Medicine, Yamagata, \\ 990-23, Japan
}

\begin{abstract}
In female mice, fertility and fecundity decrease progressively with ageing for unknown reasons. The time of day at which ovulation occurred and the time required for all the follicles to ovulate in young (10-14 weeks), middle-aged (9-1I months) and old (13-15 months) female mice were compared under controlled lighting conditions ( $12 \mathrm{~h}$ dark to $12 \mathrm{~h}$ light) to determine the relationship between maternal age and reproductive loss. The number of oocytes present in the follicles and the ampullae were counted at intervals of $\mathrm{I} \mathrm{h}$ after mating. In the groups of young and middle-aged mice, the percentage of oocytes ovulated into the ampullae increased gradually and reached almost $100 \%$ at $7 \mathrm{~h}$ after the midpoint of the dark period. Whereas, in the group of old mice, it took twice as long (15 h) to reach $100 \%$. However, the mean number of total oocytes remained relatively unchanged (young, 14.8; middle-aged, 16.2; old, 13.8). The prolongation in the time required for all the follicles to ovulate in old female mice may therefore be associated with a low fertilization rate and consequently the age-related decrease in number of offspring produced.
\end{abstract}

\section{Introduction}

It is generally assumed that ovulation in mice occurs around, or just after, the midpoint of the dark period under natural or quasi-natural lighting conditions. However, some studies have shown a variety of ovulation times in several different strains of mice (Snell et al., 1940; Braden and Austin, 1954; Whitten and Dagg, 1961; Bingel and Schwartz, 1969; Krishna and Generoso, 1977; Albanese, 1987; Boerjan and de Boer, 1990). In an earlier experiment (Ishikawa et al., 1992), it was found that in young female mice of the Jc//ICR strain ovulation started around the midpoint of the dark period under a controlled $12 \mathrm{~h}$ light: $12 \mathrm{~h}$ dark cycle. These different ovulation times may reflect differences among strains or various lighting conditions. Furthermore, it is possible that some of the apparent discrepancies are due to the ages of the mice rather than to differences among strains.

Several reports have demonstrated that there is not an age-related decrease in the numbers of ovulated oocytes in mice (Biggers et al., 1962; Harman and Talbert, 1970; Gosden, 1975), rats (van der Schoot, 1976; Matt et al., 1987a; Day et al., 1989) and hamsters (Thorneycroft and Soderwall, 1969; Mizoguchi and Dukelow, 1981). Furthermore, our literature review failed to reveal any reports comparing the duration of ovulation (the time required for all the follicles to ovulate) in mice at different ages.

In this study, the numbers of oocytes present in the follicles and the ampullae were examined more precisely at intervals of $1 \mathrm{~h}$ around the presumed time of ovulation in the three different age groups of $\mathrm{Jcl} / \mathrm{ICR}$ mice exposed to a $12 \mathrm{~h}$ dark:12 h light cycle and the duration of ovulation was

*Correspondence and reprint requests.

Revised manuscript received 31 May 1996. compared. This study is, to our knowledge, the first to examine whether the duration of spontaneous ovulation in mice is affected by increasing maternal age.

\section{Materials and Methods}

Retired breeder JCl/ICR female mice were obtained at 7-9 months of age from CLEA Japan Co. (Tokyo) and housed five or six per cage in light-controlled ( $12 \mathrm{~h}$ light: $12 \mathrm{~h}$ dark cycle; lights on from 14:00 h-02:00 h daily) and temperaturecontrolled $\left(24-26^{\circ} \mathrm{C}\right)$ rooms with food and drinking water available ad libitum. Two different aged groups were established by continuing to breed some mice up to 9-11 months (middle-aged) and others up to 13-15 months (old group). A group of young (10-14 weeks) virgin female Jcl/ICR mice was also obtained from CLEA Japan Co. and acclimatized to the same conditions for at least 2 weeks before mating (Snell et al., 1944).

Female mice were housed with male mice from the beginning of the dark period, and those with vaginal plugs were killed by cervical dislocation at appropriate intervals before and after the midpoint $(08: 00 \mathrm{~h})$ of the dark period. Previous studies have shown that mating does not affect the onset of ovulation (Snell et al., 1940; Edwards and Gates, 1959). The ovaries were placed in an embryological watch-glass containing physiological saline solution and dissected at $\times 20$ magnification under a microscope. When mature follicles were found in the ovaries (large swollen follicles with large blood vessels), they were punctured with a 25 -gauge sterile hypodermic needle. When oocytes with attached cumulus cells were found in the ampullae and fully grown oocytes surrounded by many layers of follicle cells in the follicles, the numbers of oocytes from both right 
Table 1. The number of oocytes in the ampullae and follicles in young, middle-aged and old ovulating mice

\begin{tabular}{|c|c|c|c|c|c|c|c|c|c|c|c|c|}
\hline \multirow{2}{*}{$\begin{array}{l}\text { Time from } \\
\text { midpoint of } \\
\text { dark period } \\
\text { (h) }\end{array}$} & \multicolumn{4}{|c|}{ Young } & \multicolumn{4}{|c|}{ Middle-aged } & \multicolumn{4}{|c|}{ Old } \\
\hline & $\begin{array}{l}\text { Number } \\
\text { of } \\
\text { females }\end{array}$ & Ampullae & Follicles & Total & $\begin{array}{c}\text { Number } \\
\text { of } \\
\text { females }\end{array}$ & Ampullae & Follicles & Total & $\begin{array}{c}\text { Number } \\
\text { of } \\
\text { females }\end{array}$ & Ampullae & Follicles & Total \\
\hline-2 & 10 & $\begin{array}{c}0 \\
(0-0)\end{array}$ & $\begin{array}{c}13.0 \\
(11-15)\end{array}$ & $\begin{array}{c}13.0 \\
(11-15)\end{array}$ & 7 & $\begin{array}{c}0 \\
(0-0)\end{array}$ & $\begin{array}{c}14.3 \\
(11-18)\end{array}$ & $\begin{array}{c}14.3 \\
(11-18)\end{array}$ & & & & \\
\hline-1 & 10 & $\begin{array}{r}0.9 \\
(0-9)\end{array}$ & $\begin{array}{l}13.0 \\
(2-21)\end{array}$ & $\begin{array}{c}13.9 \\
(9-21)\end{array}$ & 5 & $\begin{array}{c}0 \\
(0-0)\end{array}$ & $\begin{array}{c}15.8 \\
(14-18)\end{array}$ & $\begin{array}{c}15.8 \\
(14-18)\end{array}$ & & & & \\
\hline 0 (midpoint) & 11 & $\begin{array}{c}3.7 \\
(0-17)\end{array}$ & $\begin{array}{c}9.4 \\
(0-16)\end{array}$ & $\begin{array}{l}13.1 \\
(8-17)\end{array}$ & 13 & $\begin{array}{c}2.3 \\
(0-16)\end{array}$ & $\begin{array}{c}9.7 \\
(1-14)\end{array}$ & $\begin{array}{c}12.0 \\
(8-17)\end{array}$ & 10 & $\begin{array}{c}0 \\
(0-0)\end{array}$ & $\begin{array}{c}14.1 \\
(10-18)\end{array}$ & $\begin{array}{c}14.1 \\
(10-18)\end{array}$ \\
\hline+1 & 12 & $\begin{array}{c}5.2 \\
(0-18)\end{array}$ & $\begin{array}{c}7.4 \\
(0-14)\end{array}$ & $\begin{array}{l}12.6 \\
(9-18)\end{array}$ & 10 & $\begin{array}{c}0 \\
(0-0)\end{array}$ & $\begin{array}{c}15.4 \\
(11-18)\end{array}$ & $\begin{array}{c}15.4 \\
(11-18)\end{array}$ & 9 & $\begin{array}{c}2.6 \\
(0-13)\end{array}$ & $\begin{array}{l}13.3 \\
(4-21)\end{array}$ & $\begin{array}{c}15.9 \\
(13-21)\end{array}$ \\
\hline+2 & 14 & $\begin{array}{c}3.4 \\
(0-15)\end{array}$ & $\begin{array}{c}9.7 \\
(0-17)\end{array}$ & $\begin{array}{l}13.1 \\
(6-17)\end{array}$ & 13 & $\begin{array}{c}5.9 \\
(0-20)\end{array}$ & $\begin{array}{c}8.9 \\
(0-17)\end{array}$ & $\begin{array}{l}14.7 \\
(9-20)\end{array}$ & 11 & $\begin{array}{r}1.8 \\
(0-9)\end{array}$ & $\begin{array}{l}11.5 \\
(4-16)\end{array}$ & $\begin{array}{c}13.3 \\
(10-16)\end{array}$ \\
\hline+3 & 13 & $\begin{array}{c}8.6 \\
(0-19)\end{array}$ & $\begin{array}{c}5.4 \\
(0-15)\end{array}$ & $\begin{array}{c}14.0 \\
(10-21)\end{array}$ & 12 & $\begin{array}{c}6.7 \\
(0-16)\end{array}$ & $\begin{array}{c}7.3 \\
(0-16)\end{array}$ & $\begin{array}{l}14.0 \\
(9-17)\end{array}$ & 13 & $\begin{array}{c}9.2 \\
(0-19)\end{array}$ & $\begin{array}{c}6.4 \\
(0-16)\end{array}$ & $\begin{array}{c}15.5 \\
(11-19)\end{array}$ \\
\hline+4 & 10 & $\begin{array}{l}11.5 \\
(0-18)\end{array}$ & $\begin{array}{c}3.0 \\
(0-13)\end{array}$ & $\begin{array}{c}14.5 \\
(11-18)\end{array}$ & 8 & $\begin{array}{l}12.5 \\
(0-19)\end{array}$ & $\begin{array}{c}3.1 \\
(0-14)\end{array}$ & $\begin{array}{l}15.6 \\
(8-19)\end{array}$ & 8 & $\begin{array}{c}8.3 \\
(0-14)\end{array}$ & $\begin{array}{c}5.6 \\
(0-18)\end{array}$ & $\begin{array}{l}13.9 \\
(9-21)\end{array}$ \\
\hline+5 & 11 & $\begin{array}{l}14.2 \\
(8-19)\end{array}$ & $\begin{array}{c}1.1 \\
(0-4)\end{array}$ & $\begin{array}{c}15.3 \\
(10-22)\end{array}$ & 7 & $\begin{array}{l}10.7 \\
(0-16)\end{array}$ & $\begin{array}{c}4.4 \\
(0-13)\end{array}$ & $\begin{array}{c}15.1 \\
(11-17)\end{array}$ & 6 & $\begin{array}{l}12.8 \\
(9-15)\end{array}$ & $\begin{array}{r}2.5 \\
(0-6)\end{array}$ & $\begin{array}{c}15.3 \\
(13-18)\end{array}$ \\
\hline+6 & 8 & $\begin{array}{c}16.5 \\
(14-18)\end{array}$ & $\begin{array}{c}0.4 \\
(0-2)\end{array}$ & $\begin{array}{c}16.9 \\
(14-20)\end{array}$ & 5 & $\begin{array}{c}17.4 \\
(16-19)\end{array}$ & $\begin{array}{c}0.2 \\
(0-1)\end{array}$ & $\begin{array}{c}17.6 \\
(16-19)\end{array}$ & 6 & $\begin{array}{l}11.0 \\
(0-16)\end{array}$ & $\begin{array}{c}3.0 \\
(0-10)\end{array}$ & $\begin{array}{c}14.0 \\
(10-18)\end{array}$ \\
\hline+7 & 7 & $\begin{array}{c}15.1 \\
(13-18)\end{array}$ & $\begin{array}{c}0.1 \\
(0-1)\end{array}$ & $\begin{array}{c}15.3 \\
(13-18)\end{array}$ & 5 & $\begin{array}{c}16.6 \\
(14-19)\end{array}$ & $\begin{array}{c}0 \\
(0-0)\end{array}$ & $\begin{array}{c}16.6 \\
(14-19)\end{array}$ & 5 & $\begin{array}{c}6.4 \\
(0-10)\end{array}$ & $\begin{array}{r}4.0 \\
(0-7)\end{array}$ & $\begin{array}{l}10.4 \\
(7-15)\end{array}$ \\
\hline+8 & & & & & & & & & 5 & $\begin{array}{l}10.8 \\
(3-17)\end{array}$ & $\begin{array}{r}3.6 \\
(1-9)\end{array}$ & $\begin{array}{c}14.4 \\
(10-19)\end{array}$ \\
\hline+9 & & & & & & & & & 5 & $\begin{array}{l}10.2 \\
(6-16)\end{array}$ & $\begin{array}{c}4.0 \\
(1-10)\end{array}$ & $\begin{array}{c}14.2 \\
(10-17)\end{array}$ \\
\hline+10 & & & & & & & & & 5 & $\begin{array}{l}10.6 \\
(8-14)\end{array}$ & $\begin{array}{c}3.0 \\
(0-6)\end{array}$ & $\begin{array}{c}13.6 \\
(8-17)\end{array}$ \\
\hline+11 & & & & & & & & & 9 & $\begin{array}{c}7.8 \\
(1-16)\end{array}$ & $\begin{array}{c}2.4 \\
(0-6)\end{array}$ & $\begin{array}{l}10.2 \\
(5-16)\end{array}$ \\
\hline+12 & & & & & & & & & 6 & $\begin{array}{c}8.2 \\
(3-16)\end{array}$ & $\begin{array}{r}4.0 \\
(1-7)\end{array}$ & $\begin{array}{c}12.2 \\
(5-19)\end{array}$ \\
\hline+13 & & & & & & & & & 5 & $\begin{array}{l}11.2 \\
(7-18)\end{array}$ & $\begin{array}{r}1.2 \\
(0-3)\end{array}$ & $\begin{array}{c}12.4 \\
(8-19)\end{array}$ \\
\hline+14 & & & & & & & & & 5 & $\begin{array}{l}12.8 \\
(9-15)\end{array}$ & $\begin{array}{r}1.2 \\
(0-3)\end{array}$ & $\begin{array}{c}14.0 \\
(10-17)\end{array}$ \\
\hline+15 & & & & & & & & & 6 & $\begin{array}{l}14.7 \\
(8-19)\end{array}$ & $\begin{array}{c}0 \\
(0-0)\end{array}$ & $\begin{array}{l}14.7 \\
(8-19)\end{array}$ \\
\hline+16 & & & & & & & & & 6 & $\begin{array}{c}15.7 \\
(12-20)\end{array}$ & $\begin{array}{c}0 \\
(0-0)\end{array}$ & $\begin{array}{c}15.7 \\
(12-20)\end{array}$ \\
\hline
\end{tabular}

The range is given in parentheses.

and left follicles and ampullae were counted. At intervals of $\mathrm{I} \mathrm{h}$ the mean number of oocytes either in the follicles or in the ampullae were measured for each animal. The percentage of oocytes in the ampullae was calculated as follows: (the number of oocytes in the ampullae/the total number of oocytes both in the follicles and in the ampullae) $\times 100(\%)$. For further analysis, when the percentage of oocytes in ampullae was $>50 \%$ or $100 \%$ the female was defined as an individual with $50 \%$ or $100 \%$ ovulation, respectively. Subsequently the number of females with $50 \%$ or $100 \%$ ovulation at respective timepoints was determined by calculating the cumulative percentage of females with $50 \%$ or $100 \%$ ovulation as follows: cumulative percentage of females with $50 \%$ ovulation $=[$ (number of females that had ovulated $50 \%$ or more than $50 \%$ of total matured oocytes from the follicles into the ampullae by the time indicated)/(number of females that had ovulated $50 \%$ or more than $50 \%$ before that timepoint + females examined at that timepoint) $] \times 100(\%)$, and cumulative percentage of females with $100 \%$ ovulation $=[$ (number of females that had ovulated $100 \%$ of total matured oocytes from the follicles into the ampullae by the time indicated)/(number of females that had $100 \%$ ovulated before that timepoint + females examined at that timepoint) $] \times 100(\%)$.

Some of the data from the young group were reported by Ishikawa et al. (1992) and have been reanalysed. 


\section{Results}

Female mice in the old group were not examined at $2 \mathrm{~h}$ and $1 \mathrm{~h}$ before the midpoint of the dark period as few females had ovulated in either the young (10-16 weeks old) or middle-aged (9-11 months old) groups at these timepoints, and no females appeared to ovulate until the midpoint of the dark period in the old group (Table 1). In the young and middle-aged groups, the percentage of oocytes ovulated into the ampullae increased gradually and reached almost $100 \%$ at $7 \mathrm{~h}$ after the midpoint of the dark period; whereas in the old group at this timepoint, about $62 \%$ of oocytes ovulated into the ampullae. The percentage of oocytes that ovulated into the ampullae in the old group increased more slowly and it reached $100 \%$ at $15 \mathrm{~h}$ after the midpoint of the dark period.

In all three age groups, the cumulative percentage of females with $50 \%$ ovulation reached more than $90 \%$ by $5 \mathrm{~h}$ after the midpoint of the dark period (Fig. 1). However, although the cumulative percentage of females with $100 \%$ ovulation in the young and middle-aged groups reached more than $90 \%$ by $6 \mathrm{~h}$ after the midpoint of the dark period, it was not until $13 \mathrm{~h}$ or $15 \mathrm{~h}$ after the midpoint that the cumulative percentage of females with $100 \%$ ovulation in the group of old mice reached more than $90 \%$

In female mice with $100 \%$ ovulation, the mean number of total oocytes (the mean number of all oocytes ovulated into the ampullae) was similar in the three groups (young, 14.8; middle-aged, 16.2; old, 13.8).

\section{Discussion}

The study reported here demonstrates that the duration of ovulation is greater in old female mice than in younger mice, and that the numbers of ovulated oocytes remain relatively unchanged in ageing mice. Several reports have shown that in ageing female mice embryonic development is delayed and that the number of offpsring produced is lower, although the numbers of ovulated oocytes is similar (Biggers et al,, 1962; Harman and Talbert, 1970; Gosden, 1975). Ishikawa and Endo (1995) reported that, in middle-aged (9-11 months) and old (13-15 months) female mice, numbers of live fetuses at mid-gestation (day 8 of gestation) were lower, and embryonic development was delayed compared with those from young females, although numbers of corpora lutea were almost equal to that of young females.

The findings reported here indicate that in old female mice more time is required for all the follicles to ovulate compared with young and middle-aged mice. Consequently, oocytes from old female mice that ovulated at the end of the ovulation period would become overripe in the follicles. Parkening and Soderwall (1973) have observed that a large proportion of the oocytes released from old female hamsters had undergone degenerative changes before fertilization. In addition, several reports have shown that preovulatory over-ripeness of the ovum affects fertilization rate and results in abnormal embryonic development, chromosomal aberrations, failure of implantation, and embryonic death (Fugo and Butcher, 1966, 1971; Kamiguchi et al., 1979). These reports indicate that the preovulatory overripeness of ova in old female mice may be associated with fewer offspring.
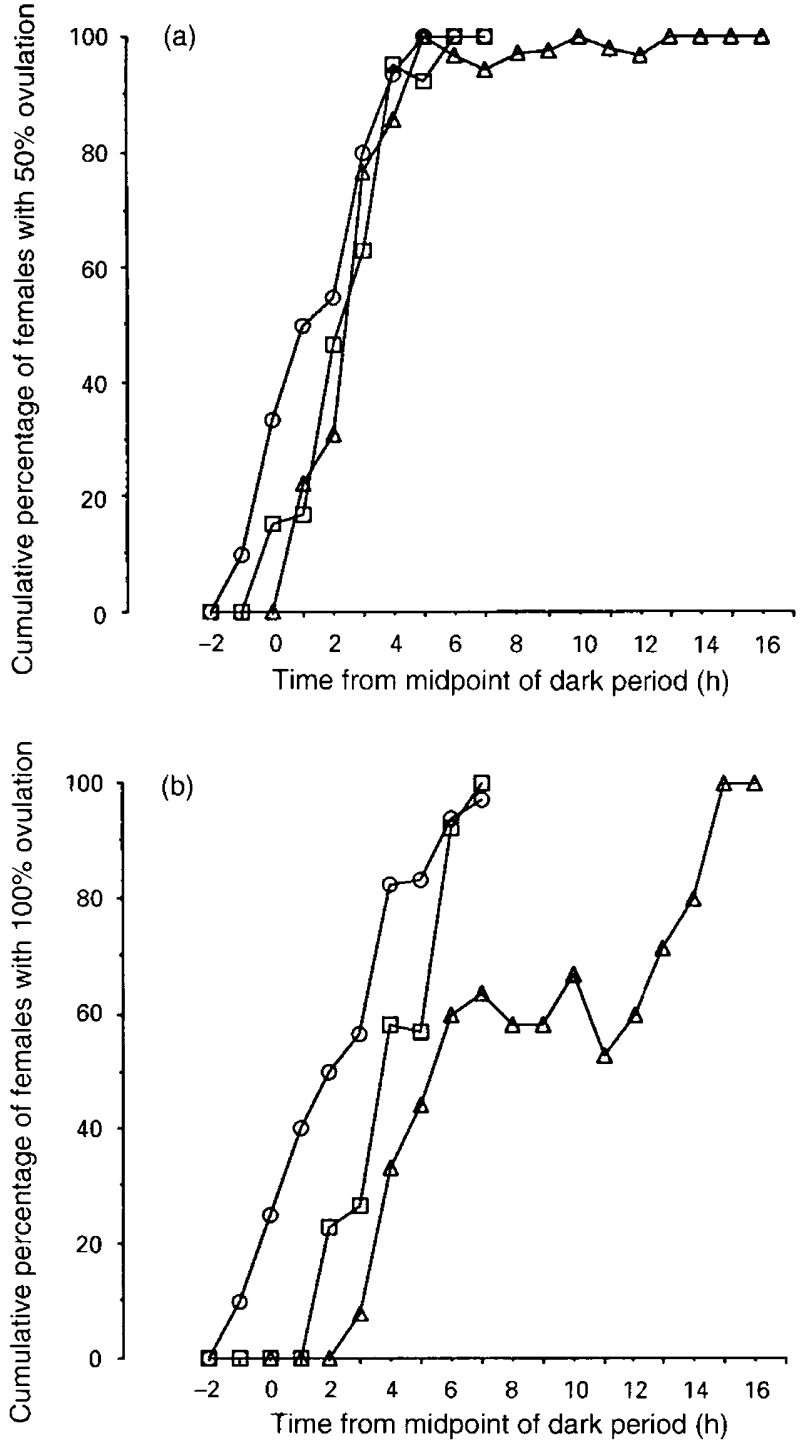

Fig. 1. The cumulative percentage of females with (a) $50 \%$ and (b) $100 \%$ ovulation for each hour before or after the midpoint of the dark period. Upper and lower line charts indicate cumulative percentage of $50 \%$ ovulation and $100 \%$ ovulation, respectively. (O) young; $(\square)$ middle-aged; $(\triangle)$ old.

Several reports have shown that the steroid-induced surge of LH is lower in middle-aged and old female rats than in younger female rats (Shaar et al., 1975; Matt et al., 1987b; Gray et al., 1980) and in mice (Mobbs et al., 1984). Furthermore, Parkening et al. (1980) suggested that there is an alteration in the mouse LH molecule with age. Thus, altered gonadotrophin secretion may also explain the findings reported here; any reduction in $\mathrm{FSH}, \mathrm{LH}$ or prolactin concentrations and delay in onset of secretion might affect follicular development, final maturation, rupture of follicles, and development of oocytes. Although circadian rhythm changes have not been reported in ageing mice, it is possible that in old mice there is some irregularity of circadian rhythm of hormones related to ovulation. The fertilization rate may also decrease at the end of the time at which ovulation is occurring, because it has been shown that the fertilizing life of mouse spermatozoa in the female 
tract was from $6 \mathrm{~h}$ to $12 \mathrm{~h}$ and their fertilizing capacity apparently decreased after $4 \mathrm{~h}$ (Merton, 1939; McGaughey et al., 1968).

Martin et al. (1976) showed that the incidence of chromosome anomalies in the oocytes increased with maternal age from young to middle-aged female mice but declined in the oldest maternal age group. In addition, Ishikawa and Endo (1995) examined cytogenetic effects of delayed fertilization in three different aged groups. However, a stepwise increase of chromosome anomalies with advancing age was not observed: the incidence in the old group was lower than that in the middle-aged group. In this study, there was a delay of $6 \mathrm{~h}$ in all groups. This seemingly paradoxical finding may be understood if it is noted that the true time interval from ovulation to fertilization in 'delayed-fertilized embryos' from the old female was not so great as had been anticipated because of prolongation of ovulation.

In conclusion, the prolongation of ovulation was demonstrated in aged females and this may have an effect on fertilization rate, abnormal embryonic development and embryonic death in early pregnancy and may thus account for the lower number of offspring produced.

\section{References}

Albanese $\mathbf{R}$ (1987) Induction and transmission of chemically induced chromosome aberrations in female germ cells Environmental and Molecular Mutagenesis 10 231-243

Biggers JD, Finn CA and McLaren A (1962) Long-term reproductive performance of female mice. II. Variation of litter size with parity Journal of Reproduction and Fertility 3 313-330

Bingel AS and Schwartz NB (1969) Timing of LH release and ovulation in the cyclic mouse Journal of Reproduction and Fertility 19 223-229

Boerjan ML and de Boer P (1990) First cell cycle of zygotes of the mouse derived from oocytes aged postovulation in vivo and fertilized in vivo Molecular Reproducton and Development 25 155-163

Braden AWH and Austin CR (1954) Fertilization of the mouse egg and the effect of delayed coitus and of hot-shock treatment Australian Journal of Biological Sciences $7552-565$

Day JR, LaPolt PS, Morales TH and Lu JKH (1989) An abnormal pattern of embryonic development during early pregnancy in aging rats Biology of Reproduction 41 933-939

Edwards RG and Gates AH (1959) Timing of the stages of the maturation divisions, ovulation, fertilization and the first cleavage of eggs of adult mice treated with gonadotrophins Journal of Endocrinology 18 292-304

Fugo NW and Butcher RL (1966) Overripeness and the mammalian ova. I Overripeness and early embryonic development Fertility and Sterility 17 804-814

Fugo NW and Butcher RL (1971) Effects of prolonged estrous cycles on reproduction in aged rats Fertility and Sterility 22 98-101

Gosden RG (1975) Ovarian support of pregnancy in ageing inbred mice Journal of Reproduction and Fertility $\mathbf{4 2} 423-430$
Gray GD, Tennent B, Smith ER and Davidson JM (1980) Luteinizing hormone regulation and sexual behavior in middle-aged female rats Endocrinology 107 187-194

Harman SM and Talbert GB (1970) The effect of maternal age on ovulation, corpora lutea of pregnancy, and implantation failure in mice Journal of Reproduction and Fertility 23 33-39

Ishikawa $\mathrm{H}$, Omoe $\mathrm{K}$ and Endo A (1992) Compensatory development in preimplantation mouse embryos derived from delayed mating Biology of Reproduction 47 782-784

Ishikawa $\mathbf{H}$ and Endo A (1995) Combined effects of maternal age and delayed fertilization on the frequency of chromosome anomalies in mice Human Reproduction 10 883-886

Kamiguchi Y, Funaki K and Mikamo K (1979) Chromosomal anomalies caused by preovulatory overripeness of the primary oocyte Proceedings Japan Academy (Series B) 55 398-402

Krishna M and Generoso WM (1977) Timing of sperm penetration, pronuclear formation, pronuclear DNA synthesis, and first cleavage in naturally ovulated mouse eggs Journal of Experimental Zoology 202 245-252

McGaughey RW, Marston JH and Chang MC (1968) Fertilizing life of mouse spermatozoa in the female tract Journal of Reproduction and Fertility 16 $147-150$

Martin RH, Dill FJ and Miller JR (1976) Nondisjunction in ageing female mice Cytogenetics and Cell Genetics 17 150-160

Matt DW, Sarver PL and Lu JKH (1987a) Relation of parity and estrous cyclicity to the biology of pregnancy in aging female rats Biology of Reproduction 37 421-430

Matt DW, Coquelin A and Lu JKH (1987b) Neuroendocrine control of luteinizing hormone secretion and reproductive function in spontaneously persistent-estrous aging rats Biology of Reproduction 37 1198-1206

Merton H (1939) Studies on reproduction in the albino mouse. Ill. The duration of life of spermatozoa in the female reproductive tract Proceedings of the Royal Society of Edinburgh $59207-218$

Mizoguchi H and Dukelow WR (1981) Fertilizability of ova from young or old hamsters after spontaneous or induced ovulation Fertility and Sterility 35 79-83

Mobbs CV, Gee DM and Finch CE (1984) Reproductive senescence in female C57BL/6J mice: ovarian impairments and neuroendocrine impairments that are partially reversible and delayable by ovariectomy Endocrinology 115 1653-1662

Parkening TA and Soderwall AL (1973) Delayed embryonic development and implantation in senescent golden hamsters Biology of Reproduction 8 427-434

Parkening TA, Collins TJ and Smith ER (1980) Plasma and pituitary concentrations of $\mathrm{LH}, \mathrm{FSH}$ and prolactin in aged female $\mathrm{C} 57 \mathrm{BL} / 6$ mice journal of Reproduction and Fertility $\mathbf{5 8} 377-386$

Shaar CJ, Euker JS, Riegle GD and Meites J (1975) Effects of castration and gonadal steroids on serum luteinizing hormone and prolactin in old and young rats joumal of Endocrinology 66 45-51

Snell GD, Fekete E, Hummel KP and Law LW (1940) The relation of mating, ovulation and the estrous smear in the house mouse to time of day Anatomical Record 76 39-54

Snell GD, Hummel KP and Abelmann WH (1944) A technique for the artificial insemination of mice Anatomical Record 90 243-253

Thorneycroft IH and Soderwall AL (1969) The nature of litter size loss in senescent hamsters Anatomical Record 165 343-348

van der Schoot P (1976) Changing pro-oestrous surges of luteinizing hormone in ageing 5-day cyclic rats Journal of Endocrinology 69 287-288

Whitten WK and Dagg CP (1961) Influence of spermatozoa on the cleavage rate of mouse eggs Journal of Experimental Zoology 148 173-183 